Jurnal Widya Laksana, Vol.11, No.1, Januari 2022

\title{
PELATIHAN PEMBUATAN BIOPORI UNTUK MENGATASI BANJIR CILEUNCANG DI DESA DEMUK, KECAMATAN PUCANGLABAN, KABUPATEN TULUNGAGUNG
}

\author{
Khusnul Khotimah ${ }^{1}$, Lailatul Fitriyah ${ }^{2}$, Rizka Arinda Yuniarti ${ }^{3}$, Khusnul Khowatim ${ }^{4}$, \\ Neni Wahyuningtyas ${ }^{5}$ \\ ${ }^{1,5}$ Prodi Pendidikan IPS, Universitas Negeri Malang \\ 2Jurusan Geografi, Universitas Negeri Malang \\ ${ }^{3} J u r u s a n$ Biologi, Universitas Negeri Malang \\ ${ }^{4}$ Jurusan Bimbingan dan Konseling, Universitas Negeri Malang \\ e-mail: khusnul.khotimah.1907416@students.um.ac.id, \\ lailatul.fitriyah.1907216@students.um.ac.id, rizka.arinda.1903416@students.um.ac.id, \\ khusnul.khowatim.201116@students.um.ac.id, neni.wahyuningtyas.fis@um.ac.id
}

\begin{abstract}
Abstrak
Desa Demuk, Pucanglaban, Tulungagung merupakan wilayah dataran tinggi berupa pegunungan kapur dengan sungai yang terputus-putus dan pola air rectangular. Namun, saluran air di Desa Demuk tidak layak dan mencukupi sehingga apabila hujan turun maka air akan meluap dan menyebabkan Banjir Cileuncang. Hal ini yang menjadi dasar penulis untuk membuat LRB dalam rangka menanggulangi Banjir Cileuncang atau genangan air di Desa Demuk. Metode yang digunakan diantaranya, analisis situasi atau persiapan, sosialisasi, pelaksanaan, dan evaluasi. Biopori ditanam sebanyak 24 buah di 3 titik yang sering terendam banjir, sehingga penanaman biopori ini efektif dalam menanggulangi genangan air meluap yang terjadi selama musim hujan. Hasil dari penanaman Biopori ini adalah terciptanya saluran air kecil di bawah tanah untuk mempermudah penyerapan air sehingga mengurangi genangan air atau Banjir Cileuncang.
\end{abstract}

Kata kunci: Banjir, Genangan air, Saluran air, Biopori, Karst

\begin{abstract}
Demuk Village, Pucanglaban, Tulungagung is a highland area in the form of limestone mountains with intermittent rivers and rectangular water patterns. However, the water channel in Demuk Village is not feasible and sufficient so that when it rains the water will overflow and cause the Cileuncang Flood. This is the basis for the author to make biopore infiltration holes in order to cope with the Cileuncang Flood or puddles in Demuk Village. The methods used include situational analysis or preparation, socialization, implementation, and evaluation. As many as 24 biopori were planted in 3 points that are often flooded, so that the planting of biopori is effective in dealing with overflowing puddles that occur during the rainy season. The result of this Biopori planting is the creation of a small water channel under
\end{abstract}


Jurnal Widya Laksana, Vol.11, No.1, Januari 2022

the ground to facilitate the absorption of water thereby reducing puddles or the Cileuncang Flood.

Keywords : Floods, Puddles, Waterways, Biopori, Karst

\section{PENDAHULUAN}

Desa Demuk merupakan salah satu desa yang berada di Kecamatan Pucanglaban, Kabupaten Tulungagung. Desa Demuk dibagi menjadi 4 wilayah yaitu Dusun Gajah Oyo, Dusun Rowo Agung, Dusun Demuk, dan Dusun Kasrepan. Secara topografis Desa Demuk merupakan wilayah dataran tinggi yang terletak di pegunungan kapur selatan Kabupaten Tulungagung, yang memiliki ketinggian kurang lebih 300 mdpl. Desa Demuk sendiri terdapat wilayah persawahan, lahan kering, dan hutan. Sumber irigasi pesawahan di Desa Demuk memanfaatkan sungai dan juga air hujan. Wilayah persawahan dan lahan perhutani terletak di bagian barat desa sedangkan lahan kering berada di bagian timur desa. Vegetasi diwilayah Desa Demuk tidak terlalu banyak hanya bagian barat yang memiliki cukup vegetasi, namun di bagian Timur atau tepatnya di Dusun Kasrepan memiliki vegetasi yang jarang dan banyak terdapat lahan kering serta memiliki elevasi yang lebih rendah dibandingkan dusun di Desa Demuk lainnya.

Kondisi sungai di Desa Demuk memiliki pola aliran rectangular membentuk sudut siku-siku dan juga terdapat pola aliran sungai terputusputus. Sungai di Desa Demuk mudah meloloskan air kedalam tanah namun ketika debit airnya besar dan tidak disertai dengan saluran air yang tidak layak (kecil) maka akan sering terjadi luapan air dan menyebabkan genangan air bahkan banjir, hal tersebut dikarenakan Desa Demuk merupakan daerah pegunungan karst. Sungai di Desa Demuk mayoritas tergolong sempit dan dangkal sehingga berdasarkan hal tersebut dapat dilihat bahwa Desa Demuk memiliki potensi genangan air atau banjir ketika terjadi hujan yang sangat deras dan dalam jangka waktu lama.

Banjir merupakan fenomena atau bencana yang sering terjadi di Indonesia terutama pada musim penghujan. Banjir dapat disebabkan oleh faktor alamiah dan aktivitas manusia, faktor alamiah ini meliputi topografi, jenis tanah, penggunaan lahan, dan curah hujan. Dalam hal ini juga perlu untuk memperhatikan kondisi sistem saluran air atau drainase air terkait daya tampung air pada jumlah atau debit tertentu. Dampak yang disebabkan oleh bencana banjir sangat beragam, baik dari aspek kegiatan manusia seperti kesehatan, sosial, pendidikan hingga ekonomi (Elsie, dkk, 2017)

Fenomena banjir di Desa Demuk terjadi secara tahunan, bencana banjir terakhir terjadi pada tanggal 6 Maret 2019. Banjir tersebut dikarenakan curah hujan yang sangat tinggi dan juga saluran air yang tidak mampu menampung air tersebut, dikarenakan saluran air atau Sungai Kasrepan yang sempit dan dangkal menyebabkan air bah yang berasal dari wilayah Kabupaten Blitar tidak dapat tertampung sehingga meluap ke 
permukaan tanah selain itu juga dikarenakan tempat pembuangan air di Desa Demuk hanya memanfaatkan resapan sungai bawah tanah, sehingga apabila sungai bawah tanah tersebut penuh dengan aliran air maka air tersebut akan kembali kepermukaan atau tidak mampu terserap dan menggenangi daratan hingga terjadi banjir. Banjir tersebut memiliki ketinggian rata-rata $100-150 \mathrm{~cm}$ dan wilayah yang terdampak paling parah yaitu di Dusun Kasrepan. Hal ini menyebabkan terendamnya puluhan hektar lahan pertanian di Desa Demuk juga banyak hewan ternak hilang dan mati.

Berdasarkan hal tersebut maka perlu untuk membuat alternatif pembuangan air yang tepat untuk meminimalisir bencana banjir di Desa Demuk. LRB merupakan salah satu alternatif yang tepat untuk mengatasi permasalahan tersebut, selain untuk mencegah banjir biopori juga dapat mencegah atau mengurangi kekeringan air dan dapat dimanfaatkan sebagai pengolah pupuk organik (Widyastuti, dkk, 2019). Teknologi LRB merupakan produk yang sederhana, dengan harga yang cukup murah serta tidak membutuhkan area lahan yang luas, selain itu proses pembuatannya cepat dan mudah (Brata \& Nelistya, 2008). Sistem LRB merupakan usaha meningkatkan kemampuan meresapkan air hujan pada tanah dengan mengendalikan aliran air permukaan (Widyastuti, et al, 2019). Biopori digunkanan untuk menyimpan, menampung, dan meresapkan air tanah (Juliandari, et al, 2013).

Biopori merupakan metode alternatif untuk meresapkan air hujan serta mengolah sampah organik, selain itu sampah organik yang dimasukkan kedalam lubang biopori juga berfungsi untuk memancing fauna-fauna di dalam tanah untuk membuat terowongan kecil sehingga air cepat meresap. Menurut Peraturan Menteri Lingkungan Hidup Nomor 12 Tahun 2009 tentang pemanfaatan Air Hujan, LRB adalah lubang yang dibuat tegak lurus ke dalam tanah, dengan diameter 10-25 $\mathrm{cm}$ dan kedalaman sekitar $100 \mathrm{~cm}$ atau tidak melebihi kedalaman muka air tanah. LRB dengan diameter $20 \mathrm{~cm}$ dan memiliki kedalaman $15 \mathrm{~cm}$ dengan jarak $2 \mathrm{~m}$ telah terbukti efektif dalam mencegah terjadinya mengalirnya air permukaan, erosi dan kehilangan nutrient di lahan pertanian (Permatasari, 2015). Sesuai dengan tujuan untuk meningkatkan resapan air ke dalam tanah, maka pemasangan LRB ditempatkan pada lokasi yang dilalui air atau tampat-tempat biasanya terdapat genangan air pada saat hujan (Widyastuti, et al, 2019).

Pada dasarnya prinsip kerja biopori yaitu memperbaiki kondisi ekosistem tanah, pada lubang tersebut jika dimasukkan sampah organik untuk mengaktifkan mikroorganisme tanah yang menguntungkan bagi kesuburan tanah, selain itu air resapan yang masuk ke dalam tanah juga ikut memperbaiki struktur tanah, dan sampah organik yang telah diolah oleh mikrobiologi akan menjadi kompos. (Yusmartini, 2021) Berdasarkan Safitri, 2019 adapun manfaat penerapan LRB adalah a) Meningkatkan jumlah air yang masuk ke dalam tanah; b) Berperan menjaga keseimbangan hidrologi tanah dan mampu mencegah adanya intrusi air laut; c) Mereduksi 
dimensi jaringan drainase hingga sampai nol jika diperlukan; d) Mengurangi konsentrasi pencemaran air tanah; e) Mempertahankan tinggi muka air tanah, f) Mengurangi limpasan air permukaan sehingga dapat mencegah banjir; dan g) Mencegah risiko terjadinya penurunan tanah. Sehingga LRB mampu meningkatkan kemampuan meresapkan air pada tanah, kemudian memperkecil peluang terjadinya genangan air dipermukaan tanah, dan pada akhirnya mampu meminimalisir terjadinya banjir (Widyastuti, et al, 2019). Selain itu, penelitian oleh Brata et al, 2008 juga menunjukkan bahwa LRB mampu meningkatkan kemampuan tanah dalam meresapkan air sehingga mampu mengurangi genangan air di permukaan.

Kegiatan pengabdian masyarakat ini bekerjasama dengan mitra yaitu Karang Taruna Desa Demuk, disini kami ingin mengajak para pemuda untuk aktif ikut serta dalam mengatasi permasalahan yang ada di desanya. Kegiatan pengabdian masyarakat ini bertujuan untuk meningkatkan pengetahuan dan ketrampilan warga masyarakat di Dusun Kasrepan, Desa Demuk, Kecamatan Pucanglaban, Kabupaten Tulungagung dalam pembuatan biopori sebagai upaya mencegah serta menanggulangi bencana banjir yang terjadi setiap tahunnya di daerah tersebut.

\section{METODE}

Pelaksanaan kegiatan program penyuluhan lubang resapan biopori dan pelatihan pembuatan lubang biopori yang dilaksanakan oleh Mahasiswa Universitas Negeri
Malang dilakukan dengan melibatkan Pemerintah Desa, Karang Taruna, dan masyarakat Desa Demuk. Program ini dilakukan dalam rangka menanggulangi dampak dari banjir cileuncang atau genangan air di daerah tersebut. Sebagian besar Pemerintah Desa dan pengurus karang taruna mengungkapkan belum mengetahui tentang alternatif penerapan biopori. Pemerintah Desa telah melakukan beberapa upaya untuk mengurangi dampak banjir cileuncang dengan pengerukan sungai tetapi hal tersebut dirasa belum efektif oleh warga karena belum adanya perubahan yang nampak secara signifikan setelah hal tersebut dilakukan. Selain itu, tidak ada upaya kembali dari pemerintah desa.

Program penyuluhan lubang resapan biopori dan pelatihan pembuatan lubang biopori ditujukan kepada pengurus Karang Taruna Desa Demuk selaku mitra kami. Kegiatan pembuatan LRB ini akan dilakukan di tiga titik daerah di RT 02 RW 01 Dusun Kasrepan yang mengalami banjir cileuncang paling parah. Lubang biopori dapat dijadikan salah satu alternatif untuk warga dalam menambah daerah serapan air yang berguna ketika datang musim penghujan serta dapat dijadikan sebagai lubang pengembalian cadangan air tanah di musim kemarau sebagai antisipasi terjadinya kekeringan.

Adapun rancangan penyelesaian masalah dari kegiatan pengabdian masyarakat ini sebagai berikut:

\section{Analisis Situasi dan Persiapan}

Beberapa hal yang dilakukan pada tahap awal yaitu sosialisasi 
Jurnal Widya Laksana, Vol.11, No.1, Januari 2022

kegiatan; pelaksanaan kegiatan; dan evaluasi kegiatan. Pada tahap persiapan dilakukan dengan cara (a) survei lokasi untuk menentukan tempat penyuluhan dan pelatihan pembuatan LRB bersama Pemerintah Desa Demuk Kecamatan Pucanglaban (b) menganalisa penyebab utama munculnya genangan air (c) mencari titik lokasi yang biasanya terdapat genangan air (d) menyusun materi panduan pembuatan dan pengelolaan LRB (LRB) serta materi mengenai dampak yang ditimbulkan akibat tergenangnya air berdasarkan analisa permasalahan yang didapat.

\section{Sosialisasi}

Sosialisasi ditujukan kepada perangkat desa dan pengurus karang taruna Desa Demuk Kecamatan Pucanglaban. Sosialisasi ini difungsikan sebagai wadah perkenalan pelaksanaan program, sasaran, dan capaian yang didapatkan selama pelaksanaan program. Pada tahap ini kelompok pengabdian meyakinkan kelompok karang taruna Desa Demuk agar bersedia untuk ikut serta membantu dalam kegiatan pengabdian hingga selesai. Hal ini bertujuan agar mitra (karang taruna Desa Demuk) dapat terus mengembangkan alternatif LRB ini ke seluruh wilayah desa yang membutuhkan meski waktu dari kelompok pengabdian telah selesai. Setelah diadakannya sosialisasi juga diharapkan untuk mitra dapat menyebarkan ilmunya terkait LRB kepada desa-desa sekitar serta menjadi rujukan desa lain untuk mengatasi banjir cileuncang atau genangan air.

\section{Pelaksanaan}

Tahap pelaksanaan dilakukan melalui dua kegiatan. Kegiatan pertama yakni penyuluhan tentang LRB. Penyuluhan dibuat untuk memperkenalkan alternatif baru yakni Lubang Resapan Biopori kepada pengurus karang taruna, mulai dari cara pembuatan sampai dengan manfaat yang dapat dirasakan. Kegiatan kedua yakni pihak Universitas Negeri Malang sebagai pembuat program akan melakukan pelatihan cara pembuatan dan pengelolaan Lubang Resapan Biopori agar manfaatnya dapat dirasakan dalam jangka waktu yang lama.

Kegiatan pegabdian masyarakat ingin sangat sesuai dengan kebutuhan warga di Dusun Kasrepan, yakni penerapan LRB guna mengantisipasi banjir cileuncing yang terjadi. Dengan dilaksanakannya pembuatan LRB, diharapkan warga Dusun Kasrepan tidak lagi khawatir dengan adanya bencana banjir cileuncang ketika musim penghujan datang. Dengan program ini diharapkan warga Dusun Kasrepan Desa Demuk dan pengurus Karang Taruna khususnya akan memiliki pengetahuan lebih dalam membuat alternatif LRB untuk mengurangi jumlah debit air yang menggenang di wilayah mereka. Sehingga kedepannya, warga Dusun Kasrepan yang dulu rumahnya tergenang air saat musim penghujan akan lebih dapat diantisipasi.

\section{Evaluasi}

Tahap evaluasi dilakukan sebagai akhir rangkaian kegiatan program LRB dan untuk melihat sejauh mana jalannya kegiatan ini dilakukan untuk 
selanjutnya dapat dievaluasi dan diperbaiki guna mewujudkan pencapaian kegiatan secara maksimal. Apabila dalam kegiatan evaluasi ini dialami kegagalan maka akan dilakukan kegiatan ulang mulai dari persiapan hingga evaluasi.

\section{HASIL DAN PEMBAHASAN}

Berdasarkan hasil pengamatan secara langsung wilayah Dusun Kasrepan RT 002 RW 001 yang terletak dibagian timur Desa Demuk yang merupakan kawasan di pegunungan yang lebih rendah dari daerah disekitarnya sehingga menjadi tempat berkumpulnya air. Selain itu, wilayah ini juga memiliki saluran air yang kurang memadai untuk mengalirkan air yang berkumpul. Kondisi sungai kurang terawat sehingga dipenuhi oleh tumpukan tanah dan pada bantaran sungai dijadikan media menanam rumput gajah sehingga fungsi utama sungai menjadi bergeser. Perubahan fungsi Sungai Pasrepan juga berdampak pada fungsi utama sungai untuk mengalirkan air dan mengangkat sedimen air menuju Daerah Aliran Sungai serta alurnya (Self Purification). (Firman, 2013)

Selain itu, disetiap rumah warga juga memiliki parit sebagai tempat untuk mengalirkan air yang berkumpul dengan tujuan akhir yakni Sungai Pasrepan. Tetapi, adanya parit ini juga tidak dapat berfungsi dengan maksimal karena mengalami pendangkalan dan tidak dirawat. Bahkan, sebagian parit sudah tidak berfungsi karena cerobong penghubungnya tertimbun dengan tanah. Bentuk parit yang tidak dirancang dengan sistem yang baik menjadikan fungsinya tidak maksimal. Sistem drainase yang kurang baik juga menjadi salah satu faktor wilayah Dusun Kasrepan kurang sering terjadi Banjir Cileuncang. Drainase merupakan serangkaian sistem bangunan air yang memiliki fungsi untuk mengurangi kelebihan air yang terdapat dalam suatu wilayah sehingga dapat mencegah banjir. Selain itu, drainase juga memiliki peran dalam mengontrol kualitas air tanah yang berkaitan dengan sanitasi, sehingga perlu adanya penataan yang terstruktur. (Hasmar Halim, 2011)

Dengan kondisi Dusun Kasrepan yang memiliki saluran air yang kurang memadai sehingga diperlukan suatu sistem yang dapat membantu peresapan air kedalam tanah. Jenis tanah yang ada di Dusun Kasrepan mayoritas adalah lempung, sehingga sulit untuk meresap air. Teknologi sederhana yang dapat diaplikasikan di Dusun Kasrepan ini adalah LRB. Pemasangan LRB sebagai upaya dalam pengaturan keseimbangan pada wilayah yang memiliki daerah peresapan yang sedikit atau sulit. (Hilwatullisan, 2011) Kemampuan setiap tanah dalam menampung ilfiltrasi air permukaan baik itu meteorik ataupun air limpasan berbeda. Tanah lempung memiliki kemampuan menampung air $66 \%-75 \%$ dari volume total tanah. (Kristanto and Helmi, 2019)

LRB atau LRB adalah alternatif media yang dapat digunakan untuk mengurangi Banjir Cileuncang yang ada di Dusun Kasrepan. LRB dipilih sebagai solusi untuk mengatasi banjir cileuncang yang ada di Dusun Kasrepan karena memiliki efektivitas 
yang tinggi dan hanya memerlukan biaya yang cukup terjangkau untuk pembuatannya. LRB membantu mengalirkan air genangan kedalam tanah dengan lebih cepat karena dengan adanya LRB maka akan terbentuk resapan-resapan baru yang dibuat oleh makhluk tanah. Alasan lain dalam pemilihan LRB sebagai media penyerapan adalah proses pembuatannya yang cukup mudah dan membutuhkan alat-alat yang sederhana. Sehingga diharapkan setelah adanya penyuluhan dan pemasangan LRB pada tiga titik terdampak, masyarakat dapat meneruskan kembali program ini pada wilayah-wilayah yang belum terjangkau oleh program ini.

Pemasangan LRB dilaksanakan dalam beberapa tahapan. Tahapan pertama adalah melakukan komunikasi dengan berbagai pihak yang terkait. Adapun pihak yang terlibat antara lain kepala desa, perangkat desa, kepala dusun, ketua karang taruna, ketua RT, serta masyarakat dusun kasrepan yang mengalami dampak terparah banjir. Komunikasi dilakukan dengan tujuan penyampaian permasalahan yang ada di Dusun Kasrepan berupa banjir cileuncang serta alternatif penyelesaian yang ditawarkan. Selain itu, dengan adanya komunikasi ini juga membantu kami dalam menentukan lokasi terdampak banjir cileuncang. Sehingga dengan adanya komunikasi ini didapatkan bahwa Dusun Kasrepan merupakan dusun terparah yang mengalami banjir cileuncang, dibandingkan dengan dusun lain yang ada di Desa Demuk Kecamatan Pucanglaban Kabupaten Tulungagung.
Tahap kedua adalah melakukan observasi lokasi dan persiapan kegiatan penyuluhan LRB. Kegiatan observasi didampingi oleh kepala dusun dan ketua RT setempat. Kegiatan ini diawali dengan memperkirakan lokasi yang mengalami titik terparah banjir cileuncang. Setelah mempertimbangkan beberapa hal, maka kami memilih tiga titik yang menjadi lokasi terdampak banjir cileuncang dengan intensitas yang cukup tinggi. Pasalnya, daerah tersebut merupakan kawasan yang lebih rendah dari daerah sekitarnya sehingga menjadi titik berkumpulnya air. Hasil pada tahapan ini adalah ditentukannya tiga titik pemasangan LRB yang merupakan titik terparah banjir cileuncang.

Tahap ketiga dalam pemasangan LRB adalah melakukan penyuluhan kepada karang taruna mengenai LRB. Karang taruna dipilih sebagai mitra dalam kegiatan ini karena memiliki potensi yang besar untuk dapat menindak lanjuti kegiatan ini pada lokasi-lokasi lain yang belum memiliki LRB dan berpotensi menjadi titik terparah banjir cileuncang. Penyuluhan tersebut menjelaskan mengenai latar belakang pelaksanaan program, pemaparan kondisi atau permasalahan yang menjadi objek kegiatan, berbagai opsi solusi untuk menyelesaikan masalah, pengenalan biopori, kegunaan biopori, mekanisme kerja biopori, cara pembuatan biopori, serta alat dan bahan yang digunakan dalam proses pembuatan dan pemasangan LRB. Selain menyampaikan penyuluhan melalui media ceramah dan powerpoint, kelompok pelaksana pengabdian juga 
membaca contoh konkrit pipa yang digunakan dalam pembuatan LRB serta alat pendukung lainnya.

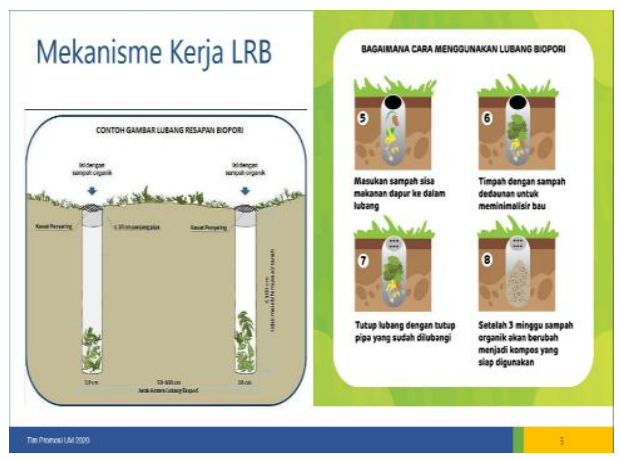

Gambar 1. Materi penyuluhan

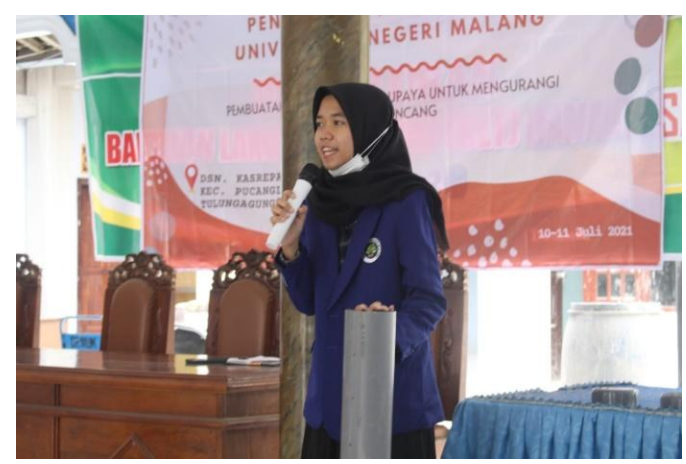

Gambar 2. Proses sosialisasi

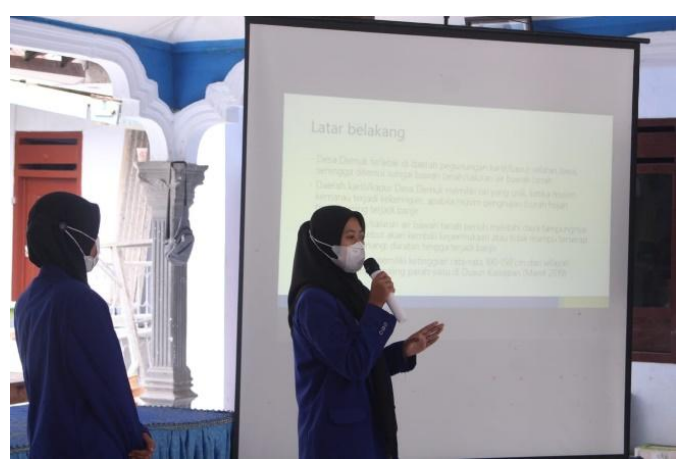

Gambar 3. Pengenalan LRB
Tahapan keempat yaitu proses pembuatan pipa LRB. Proses pembuatan LRB dimulai dengan memotong pipa yang memiliki diameter $10 \mathrm{~cm}$ dengan panjang $80 \mathrm{~cm}$. Setelah pipa dipotong, pipa diberi lubang kecilkecil atau pori-pori dengan jarak antar lubang $5 \mathrm{~cm}$. Selain memberikan poripori atau lubang pada pipa, tutup pipa juga wajib diberi lubang dengan pola melingkar dan jarak antar lubang $1 / 2 \mathrm{~cm}$.

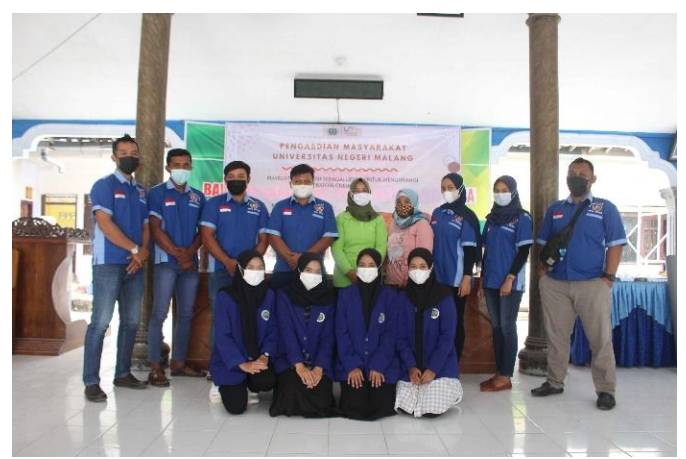

Gambar 4. Dokumentasi kelompok pelaksana bersama karang taruna dan pemerintah Desa Demuk

Tahapan kelima yakni proses pemasangan LRB. Pada tahapan ini terlebih dahulu kelompok pelaksana meninjau lokasi untuk kedua kalinya untuk menentukan titik-titik penempatan LRB. Setelah penentuan titik selesai, keesokan harinya kelompok pelaksana program beserta karang taruna memasang LRB pada tempat-tempat yang telah ditentukan. Pada kegiatan ini, panitia membagi tugas agar lebih terstruktur. Kelompok pertama, mencari sampah organik dan memasukkan kedalam pipa dan kelompok kedua melubangi tanah menggunakan alat pelubang tanah dan linggis untuk membuat ruang tanah yang akan 
Jurnal Widya Laksana, Vol.11, No.1, Januari 2022

menjadi tempat peletakan LRB. Tanah dilubangi dengan jarak antar lubang 1 meter dan kedalaman $80 \mathrm{~cm}$.

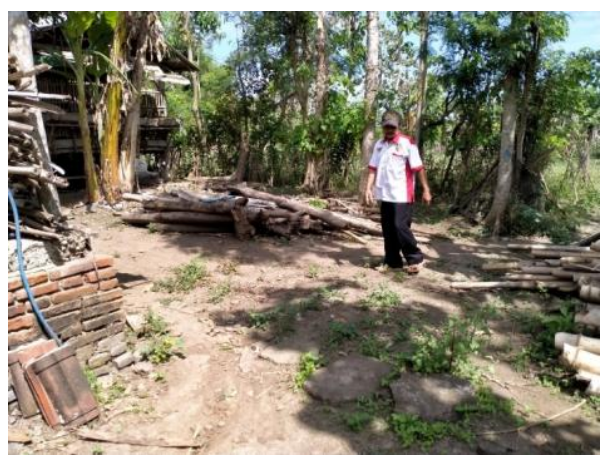

Gambar 5. Penentuan titik pemasangan LRB

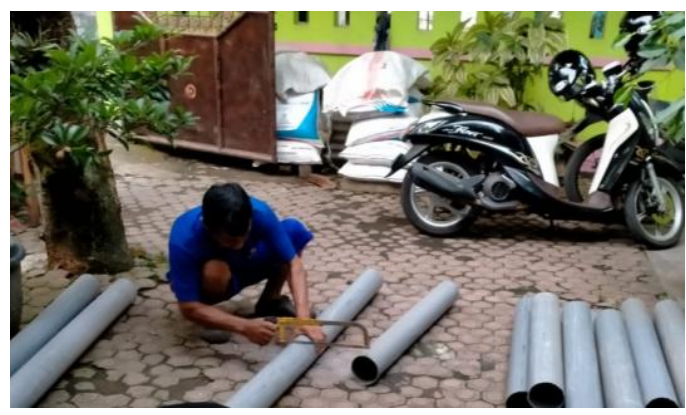

Gambar 6. Proses pembuatan LRB

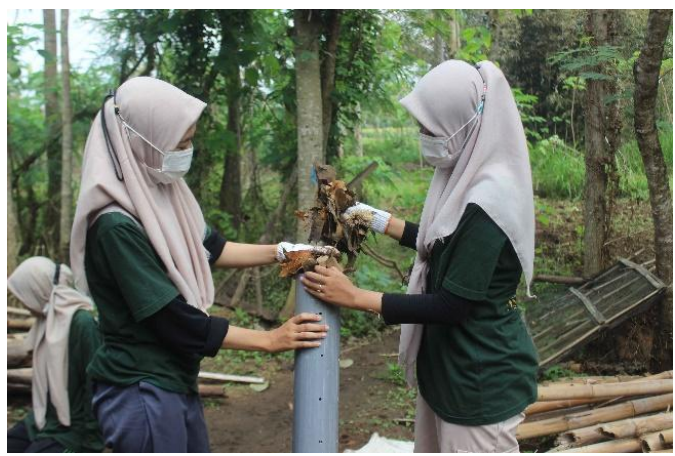

Gambar 7 Proses memasukkan sampah organik kedalam LRB

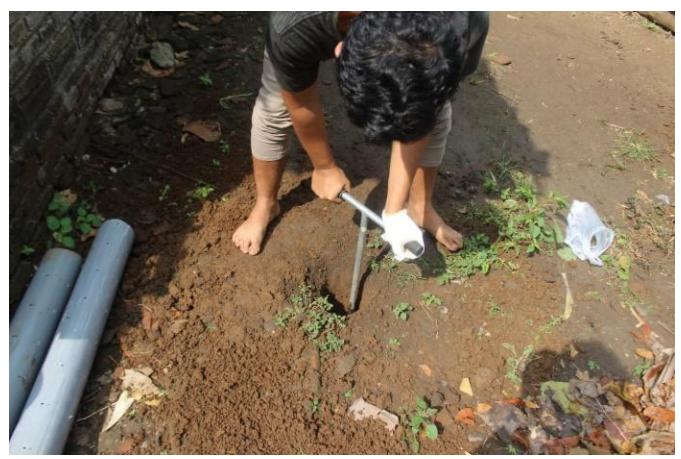

Gambar 8. Proses pembuatan lubang tanah menggunakan alat biopori

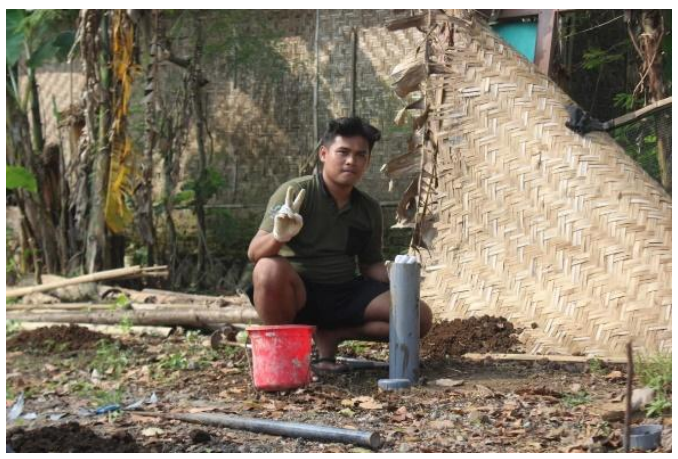

Gambar 9. Proses memasukkan LRB kedalam tanah

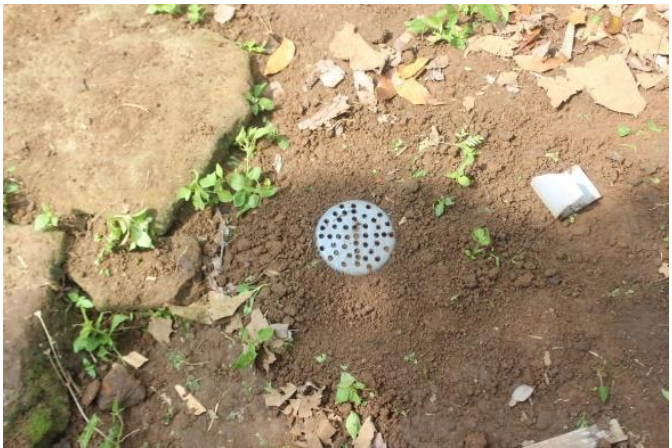

Gambar 10. LRB setelah berhasil ditanam di dalam tanah 
Berdasarkan hasil analisis yang dilakukan oleh kelompok pelaksana pengabdian masyarakat, maka dapat disimpulkan bahwa banjir cileuncang yang terjadi di Dusun Kasrepan disebabkan oleh berbagai faktor, baik faktor alam maupun non alam. Adapun faktor alam yang menyebabkan genangan air di Dusun Kasrepan yakni 1) Topografi Dusun Kasrepan lebih rendah dari daerah sekitarnya, sehingga menjadi titik kumpul air. 2) Jenis tanah yang ada di Dusun Kasrepan adalah tanah lempung sehingga sulit untuk menyerap air. 3) Pola aliran sungai memiliki pola aliran rectangular membentuk sudut siku-siku dan juga terdapat aliran sungai terputus-putus. Selain itu, banyak sungai yang berada dibawah tanah, sehingga jika hujan memiliki curah yang tinggi air yang tidak dapat tertampung dalam sungai bawah tanah tersebut akan meluap. Adapun faktor non alam yang dapat menyebabkan genangan air yaitu 1). Rendahnya kesadaran warga dalam merawat DAS 2). Aliran air atau selokan yang berada didepan rumah warga tergolong sempit dan dangkal.

Proses pelaksanaan kegiatan penyuluhan dan pemasangan LRB di Dusun Kasrepan Desa Demuk Kecamatan Pucanglaban secara umum berjalan dengan baik. Komunikasi, koordinasi, serta kerjasama yang dilakukan antara pihak penyelenggara program dan mitra kegiatan berjalan dengan baik. Dusun Kasrepan sebagai lokasi pembuatan LRB telah memenuhi kriteria-kriteria dalam pelaksanaan program serta memiliki kesesuaian dengan topik cakupannya. Pada tahapan penyuluhan dan pemasangan LRB berjalan dengan lancar. Mitra kegiatan memiliki antusias yang tinggi serta kooperatif dalam melaksanakan program penyuluhan dan pemasangan LRB. LRB yang ditanam sejumlah 24 buah yang tersebar dalam 3 titik. Efektivitas kebermanfaatan LRB cukup baik, hal ini terlihat dari proses yang dilakukan oleh kelompok pelaksana secara berkala di titik pemasangan tersebut. LRB dapat membantu pembuatan kompos secara mandiri sehingga menjadi suatu langkah penghematan biaya dalam pemanfaatan pupuk organik. (Wiratini, 2015)

Pada akhir kegiatan peserta menyampaikan pesan berdasarkan kegiatan pengbdian yang telahdilaksanakan. Adapun pesan yang disampaikan peserta kegiatan adalah sebagai berikut: 1).Peserta memerlukan modul pendamping sebagai panduan pembuatan LRB. Modul merupakan sebuah karya tulis yang dibuat dengan tujuan agar peserta dapat belajar secara mandiri tanpa atau dengan bimbingan. Modul biasanya terdiri dari alat dan bahan serta cara pembuatan 2). Wilayah pemasangan LRB diperluas, mengingingat beberapa wilayah juga menjadi tempat langganan banjir cileuncang 3 ). Pendampingan secara berkala dari kelompok pelaksana pengabdian masyarakat.

Adapun hal yang dapat kita lakukan agar LRB yang telah dibuat dapat bertahan lama antara lain yaitu: 1). LRB diusahakan untuk selalu terisi dengan sampah organik 2). Sampah organik yang berasal dari sampah rumah tangga atau sampah dapur bisa diambil untuk dijadikan pupuk setelah dua minggu, sementara jika sampah yang ada didalam LRB merupakan 
Jurnal Widya Laksana, Vol.11, No.1, Januari 2022

sampah kebun maka dapat menjadi kompos setelah dua bulan. Waktu pembuatan kompos berkaitan dengan jenis sampah tempat pembuatan LRB. Jika tanah yang menjadi media LRB merupakan tanah lempung, maka prosesnya membutuhkan waktu yang lebih lama.

\section{KESIMPULAN}

Pembuatan Biopori dilakukan untuk menanggulangi genangan air atau bahkan banjir yang terjadi di Desa Demuk yang merupakan pegunungan karst. Biopori ditanam sebanyak 24 buah di 3 titik yang sering terendam banjir. Hasil dari penanaman Biopori ini adalah terciptanya saluran air kecil di bawah tanah untuk mempermudah penyerapan air sehingga mengurangi genangan air atau Banjir Cileuncang. Biopori juga berisi sampah organik sehingga dapat digunakan sebagai pupuk alami di daerah yang ditanami dengan biopori tersebut. Setelah penanaman dilakukan, genangan air selama musim hujan dapat terkendali di Desa Demuk sehingga biopori ini dapat dikatakan efektif menangani banjir cileuncang di Dusun Kasrepan Desa Demuk.

\section{DAFTAR PUSTAKA}

Brata KR, Purwakusuma W, Hidayat $Y$, Dwiwahyuni E, Baskoro DPT. (2008). Keunggulan dan manfaat Biopori. Tersedia pada: http://www.biopori.com.

Brata, R. \& A. Nelistya. 2008. LRB. Jakarta. Penebar Swadaya

Elsie. Harahap, Israwati. Herlina, Nofripa. Badrun, Yeeri. dan Gesriantuti, Novia. 2017.
Pembuatan Lubang Resapan Biopori sebagai Alternatif Penanggulangan Banjir di Kelurahan Maharatu Kecamatan Marpoyan Damai Pekanbaru. Jurnal Untuk Mu negeri: Vol 1 (2).

Firman (2013) 'Pengelolaan Sumber Daya Air Di Daerah Aliran Sungai', Journal of Chemical Information and Modeling, 53(9), pp. 1689-1699.

Hasmar Halim, H. . (2011) 'BAB II LANDASAN TEORI 2.1 Pengertian Drainase', pp. 4-35. Available at: http://eprints.polsri.ac.id/1241/3/ BAB II.pdf.

Hilwatullisan (2011) 'Lubang Resapan Biopori (LRB) Pengertian Dan Cara Membuatnya Di Lingkungan Kita', Media Teknik, Vol. 8(No. 2), p. Hal. 1-11.

Juliandari, M., Nirmala, A., \& Yuniarti, E. (2013). Efektivitas Lubang Resapan Biopori Terhadap Laju Resapan ( Infiltrasi ). Jurnal Teknologi Lingkungan Lahan Basah, 1(1), 1-10. Retrieved from

jurnal.untan.ac.id/index.php/jmtl untan/ article/view/3441

Kristanto, W. A. D. and Helmi, H. (2019) 'Daya Tampung Tanah Terhadap Infiltrasi Air Permukaan Pada Kasus Genangan Area Persawahan Desa Katekan, Gantiwarno, Klaten.', Kurvatek, 4(1), pp. 7987. doi: 10.33579/krvtk.v4i1.1117. 
Jurnal Widya Laksana, Vol.11, No.1, Januari 2022

Permatasari, L. 2015. Bioinfiltration Hole: "One Day For Biopore" as an Alternative Prevent Flood. International Journal of Advances in Science Engineering and Technology: Vol 3 (2).

Safitri, Ratna. Purisari, Rahma. dan Mashudi, Muhammad. 2019. Pembuatan Biopori dan Sumur Resapan untuk Mengatasi Kekurangan Air Tanah di Perumahan Villa Mutiara, Tangerang Selatan. Jurnal Ilmiah Pengabdian kepada Masyarakat: Vol 5 (1)

Widyastuti, Anak Agung Sagung Alit. Adnan, Abdul Haqqi, dan Atrabina, Nurul Arijah. 2019. Pengolahan Sampah Melalui
Komposter Dan Biopori Di Desa Sedapurklagen Benjeng Gresik. Jurnal Abadimas Adi Buana: Vol 3 (1).

Wiratini, Ni Made. Maryam, Siti. Retug, Nyoman. \& Laisa, Ketut. (2015). Pelatihan Membuat Kompos dari Limbah Pertanian di Subak Anakan Desa Mas Kecamatan Ubud. Jurnal Widya Laksana: Vol. 4(2)

Yusmartini, E.S., Mardwita, Fahmi, Innike Abdillah. (2021). Sosialisasi Pengolahan Lindi menjadi Pupuk Cair di TPS-3R Kelurahan Talang Kelapa Kecamatan Alang-Alang Lebar Palembang Sumatera Selatan. Jurnal Widya Laksana: Vol. 10(1) 